\title{
Colonial Literacy and the Socio-Political Dimensions of the History Syllabus in Colonial Botswana
}

\author{
Lily Mafela \\ University of Botswana, Botswana
}

\begin{abstract}
The current Botswana history syllabus still retains strong traces of its colonial origins. The colonial history syllabus was part of a broader colonial education agenda. Western education amongst Batswana education began with informal literacy training focusing on the rudiments of reading and writing, to address the basic requirements of missionary bodies. It was gradually expanded to fully-fledged colonial subject-differentiated curricula. Each subject played a specific ideological role in the colonial milieu. In the case of history, the syllabus and content were defined by the prevailing political discourse, which placed imperial history at the core of the history syllabus and generally sidelined local indigenous histories. This was in keeping with the broader socio-political context and the dynamic relationships between the colonial government and the dikgosi (chiefs). This relationship ensured gradual accommodation of hegemonic Tswana epistemologies into the history and social studies curricula. The article places the history syllabus within the broader dynamics of an evolving colonial education policy in colonial Botswana.
\end{abstract}

\section{Introduction}

In many parts of Africa, an inherited colonial curriculum presented serious challenges to postcolonial attempts at nation-building. These challenges included issues of indigenous language marginalization and ethnic tension [1] [16]. In Botswana, colonial policies exacerbated existing ethnic tensions, which manifested themselves in the curricula content of specific subject syllabi. Consequently, in 1966 Botswana inherited a curriculum that was characterized as foreign in nature, due to its "strong traces of European origin" [7]. Thus, the post-independence post-colonial Batswana leaders were particularly concerned about the role of education in promotion of tribalism and in impeding the achievement of nationhood [24].
The First National Commission on Education was tasked with the responsibility of ridding the Botswana curriculum of its alienating nature [6], to ensure that it could be used as a vehicle for a detribalized and national school curriculum. To this end, there have been attempts to come up with other versions of the written history of Botswana, which reflect the prevailing socio-cultural revival. The basis for this revival is the growing assertiveness of the socalled minor ethnic groups, which reflect the global ideas and global trends in which indigenous minorities, with the involvement and assistance of the NGO's, the UN-wide programs seek to promote inclusiveness in post-colonial discourse.

These (revisionist) historical versions have been partially made possible by the growth of scholarship at the University of Botswana, the autonomy with which scholars generally operate, and in particular the BA essays which have been carried out under the auspices of the History Department since the late 1970's. Amongst these essays, there have been some that have dealt specifically with the origins of some minority groups, which question prevailing notions of the histories of groups, such as Bakalanga and Babirwa [5] [19] [14] [25]. These historical accounts even go so far as to explore controversial issues, which reflect the conflicts between these subject groups and their overlords [25].

In spite of the rich data produced as a result of post-colonial historical research, recent historical accounts have not yet found their way into school history textbooks, because the education system has not been adequately accommodating, due to the wider socio-political tensions, which were inherited from then past. This situation demonstrates that the history curriculum still is, as it was in the past, the cornerstone of socio-political engagement and tension. This is primarily because history is the most political and culturally sensitive of subjects, because of the manner in which it relates to an often highly politicised public discourse over national identity [27]. Thus, while tensions were created by the colonial curriculum, to some extent they reflected the collaboration between colonial government and the recognized Tswana traditional leadership of principal groups. These relationships ensured that the histories 
of these groups were not completely excluded, relative to those of the minority groups. In this way, colonial policy and practice exacerbated the unequal relationship between the principal and minority ethnic groups in colonial Botswana.

The alienating curriculum of the postindependence curriculum gradually developed from a wider colonial education framework, in which history served a particular ideological role. In this framework, the history syllabus and content were part of a gradually developing literacy that was initiated by missionary bodies in the mid- $19^{\text {th }}$ century. From the early part of the $20^{\text {th }}$ century, basic literacy gradually became more defined into an elaborate subject-differentiated curriculum, in line with the emerging colonial needs.

The purpose of this article is to trace the development of history as a school subject, and to highlight its role in the dynamic socio-political milieu of colonial Botswana. The paper will also discuss how these historical developments have influenced the current challenges in regard to the Botswana history syllabus.

Textual analysis of archival documents including colonial office syllabi and secondary sources were used in this work. It is important to point out that in some cases the article relied on secondary analysis of some of the texts mentioned here. These were not all perused first hand by the author, due to the fact that these texts, some of which date back to the $19^{\text {th }}$ and early $20^{\text {th }}$ centuries were difficult are particularly difficult to trace. Future research should focus on the further search for, and deeper analysis of these works.

\section{Ethnic differentiation and socio- political domination}

Ethnic differentiation in Botswana predates colonization of the land of Batswana. As far back as the early 1800's, the Tswana state began undergoing transformation of its socio-economic and political structures, which had important ramifications for ethno-cultural intercourse. Characterized by a common socio-economic dispensation among the principal Tswana groups, there was a general tendency towards entrenchment of class distinction which became conflated within the ethnic differentiation that was taking shape.

While the colonial government did not create ethnic differentiation, colonial political and juridical discourse upheld at the least, and exacerbated at the most the pre-colonial ethno-cultural dispensation. The use of traditional authorities particularly in the laissez-faire period-when the dikgosi were allowed wide latitude in their reign over their people, prior to the introduction of juridico-legal measures designed to curtail their powers-objectified Tswana ethnocultural pre-eminence.

The colonial government recognized only eight principal ethnic groups, which were given prominence by various colonial practices and policies. For example, the colonial government had elected to apportion land according to a system of reserves, which were assigned to particular dikgosi of the recognized (usually numerically) superior ethnic groups. This system had no inbuilt provision for recognition of groups that were either had no dikgosi, or which were otherwise regarded as "subject" groups even if they had distinct areas of their own land, distinct cultures, traditions and histories. They were simply all lumped for administrative convenience, and all deliberations were conducted with the "principal" dikgosi."

Although they were a colonized people and had many of their powers circumscribed, Batswana dikgosi were partners to, and collaborators with the colonial government on many issues. Proclamations number 34 and 35 were particularly far-reaching in terms of changes to the hitherto unfettered powers of dikgosi.

The division of Batswana land into reserves further consolidated the control and authority of Batswana principal groups over the "subject" groups, where the latter was placed under the custodial overlordship of the former. Up until 1934 when their powers were curtailed, the dikgosi of the principal groups had enjoyed a period of relative and collaborative engagement with the colonial government, where few if any stops were placed on their over-lordship of other the ethnic groups.

The intensification of the cash economy and the contradictions of the emergent colonial political discourse rearranged relations between the dominant Tswana and the minority groups. This enabled them to gain political pre-eminence, which gradually evolved into socio-cultural dominance as well. This trend was exacerbated by colonial policies generally, which pitted groups against each other. As in many parts of Africa, the divide and rule tactics of British colonial administration also exacerbated matters, in addition to the creation of artificial and seemingly arbitrary colonial boundaries that split ethnic communities.

The colonial discourse generally placed the dominant (royalty) and their functionaries at the centre, whilst minority group epistemologies were sidelined. Thus, whilst pre-colonial Tswana society had begun to manifest ethno-cultural differentiation, colonial discourse further exacerbated it. To this end, colonial authorities always made the assumption, which gained currency and credibility in Tswana society that Batswana of proto-Tswana groups were more intelligent and somehow better than the other groups which had settled among them. This 
statement below, made by one colonial official pitting a Morolong against a Mokgalagadi, clearly brought out this point:

...I interviewed the headman of the
district meanwhile: curiously enough
he is a Morolong and he is of course
more intelligent than the
Bakgagalagadi [22].

The Barolong are one of the dominant sociocultural groups in Botswana, whilst the Bakgalagadi are a subjugated minority group. The not-so subtle innuendo of tribal superiority comes out clearly in this quotation, and constitutes an example of linguistic domination of minority language speakers by Setswana speakers. Consequently, the language of Batswana principal groups evolved as the language of officio-political discourse and it became the language of deliberation in the parallel "native" administration [2]. To this end, it was used in the kgotla and in the deliberations of the Native Advisory Council. Thus, while regional vernaculars were allowed in the lower years of primary schooling, colonial policy gradually urged and increasingly enforced the use of Setswana in higher primary schools levels.

\section{The development of basic literacy and formal schooling}

Literacy predated colonization and began with the commencement of missionary activity amongst Batswana in the early part of the $19^{\text {th }}$ century. Provision of basic literacy even preceded the introduction of formal schools [8]. It became the foundation and bedrock of missionary activity, as the reading of the bible and simple writing were considered to be crucial for conversion to Christianity and Christian living. In their proselytizing activities, missionaries saw the value of teaching Batswana the rudiments of reading and writing, primarily in order to facilitate their reading and understanding of the bible. By the time the first schools were established, basic literacy training was part and parcel of the interaction between missionaries and the indigenous communities.

The first formal schools were established in the southern part of colonial Botswana in the 1850's and 1860 's by the various missionary bodies in Bechuanaland Protectorate [8]. In 1910, the total Bechuanaland school enrolment was 1,375, of which only 396 were boys, and 979 girls, signifying a ratio of a little under 1:3 in favor of girls. Over the next two decades, school enrolments rose markedly, totaling 4,559 in 1920, and 7,960 in 1932. Of the 7,960, 2,551 were boys, and 5,409 girls. The latter growth indicates that male enrolments had grown by almost seven times, while girls' enrolments had grown by between five and six times [4]. Enrolments reached a record 15,390 pupils in 1938 [4] and in 1946 rose to 21, 174 pupils in primary schools and 50 pupils in the newly initiated secondary schooling [9].

The increase in enrolments was associated with the changes that were instituted in the educational system. These changes were linked to related transformations in the nature of colonial policy and relationships, as well as the changes in the attitude of Batswana themselves towards western education and its perceived benefits.

Batswana gradually and increasingly usurped western education as they recognized its significance in the emerging political economy. Related to this trend, was the development of what could be termed a struggle for the school and for education. In this regard, the communities formed parallel schools to those of missionaries and even taught parallel curricula, prior to the central control of curricula after 1905. Some communities employed white teachers to teach English, a coveted language because it was associated with westernization and their perceptions of civilization. A case in point is that of Bangwato leadership who employed a white teacher for the community and imposed a levy to raise funds to pay for her services [10].

Generally, communities set up parallel schools, in order to teach subjects that they felt were inadequately catered for in missionary schools, such as English and industrial education. It is important to note that due to the cost and opportunity associated with schooling, the first schools were monopolized by the royalty and other influential members of the community, who were also the first to access Christianity and its associated benefits [14].

In Botswana, the British colonial government sought to use education to address to teach the habits of industry, and to offer basic literacy to enable Batswana to perform clerical and semi-skilled tasks. Hence education was carefully designed and monitored so as to prevent the emergence of subversive elements in the society, as had been the case in the Indian sub-continent [14]. Thus, in Bechuanaland, as in other parts of Africa, while the education of the indigenous populace was left in the hands of missionaries for most of the colonial period, the fear that education could be used as a subversive tool influenced the British colonial government's policy to control the curriculum. Thus, while the colonial government did not initially assume full administration of education from 1905, it sought to exert control by giving minimal grants-in-aid to mission societies, establishing standard curricula guidelines and instituting school inspections. 
As the mission curriculum became more defined, it also offered the three R's (reading, 'riting and 'rithmetic), as well as geography (initially geography of the Bible lands), drawing, singing and music drill. These subjects were offered in addition to religious instruction and domestic science for girls and woodwork, carpentry and agriculture for boys. This subject menu was a blueprint of the syllabus known as the Cape Code.

Missionary and colonial education initially focused on informal training and gender specific courses. However, as education became more entrenched, some subjects formed the core of the school menu, and were the cornerstone of literacy and numeracy training during the colonial period. Due to the ideological role of education, different subjects performed different roles. English was usurped as a subject associated with civilization, when early on Batswana, like other colonized people elsewhere, realized its potential as a means to securing employment as interpreters and clerks in the burgeoning civil service. To this end for example, in while the colonial government remained resolute in the pre-World War II period that education of the indigenous was to be carried out in the vernacular, to the indigenous people literacy was synonymous with learning English. As the late Zimbabwean leader Reverend Ndabaningi Sithole recalled of colonial education:

To us education meant reading books, writing and talking English, and doing arithmetic...At our homes we had done a lot of ploughing, planting, weeding and harvesting... We knew how to do these things. What we knew was not education: education was what we did not know. We wanted as we said in Ndebele, "to learn the book until it remained in our heads, to speak English until we could speak it through our noses.’[23]

The usurpation of English by the indigenous communities continued to be further strengthened by the increasing association of English literacy with "civilization" and employment.

\section{The content and context of the colonial history syllabus}

The Cape Code was used as the blueprint for African school syllabi in the Southern African subregional British dominions of South Africa, Bechuanaland, Basutoland and Swaziland. It provided curricula uniformity commensurate with the socio-economic and political hegemony of the region. In colonial Botswana, the adoption of the Cape Code was an affirmation of the socio-political incorporation of the country into the wider Southern African educational system that was controlled from the sub-regional seat of the British colonial government in the Cape, where the British High Commissioner was based.

The Cape Code history syllabus was the working syllabus for the early part of the colonial period. It would appear that when history began to be taught as a separate subject in primary schools from 1931 onwards the Cape Code was replaced by the Bechuanaland Protectorate Code. The 1931 Bechuanaland Code was strongly influenced and retained many elements of the Cape Code on which it was based. The Cape Code featured the history of Bible Lands, History of Empire [3].

School history was not well defined initially, as it was combined with Geography and Nature Study. Nature study was another subject which increasingly occupied an important part of the colonial syllabus, due to growing concerns about diseases. As an ideological tool and as an aspect of overall education, literacy was controlled through the curricula provisions and stipulations that became part and parcel of western colonial education of Batswana. This followed the introduction of grantsin aids to missionary bodies from 1905, which served to entrench and enforce restrictive colonial curricula, in line with the needs of the colonial government. There were essentially layers of control in that while the colonial government exerted control over the curricula, the actual teaching of it was negotiated and refracted through the tenuous relationships between the principal and subordinate groups.

As noted previously, before its introduction as a separate subject, history had always been taught as part of the General Knowledge subject, which mainly comprised history and geography. History was also taught as part of a general social studies course, as well as in the Setswana subject, where the reader consisted of historical tales written in Setswana. From the 1940s history appeared as a distinct subject in a more defined curriculum alongside English, Elementary Biology and Hygiene, Scripture, Elementary Mathematics, Setswana, Geography, Agriculture for boys, domestic science for girls, and Craftwork [26].

The history content primarily featured the history of Britain and church history, with an emphasis on bible lands and the colonial process-including colonization and the functioning of the colonial administrative structure-from a purely Euro-centric perspective. Much of the history that was taught during the missionary and colonial periods reflected firstly, Britain's political hegemony, and secondly, the Tswana hegemonic context. In this context, Batswana were presented monolithically, as a people 
with a singular identity deriving from their purported common origins, which regarded them all as originating from a common founder, Masilo. Historical versions of Batswana origins in the education system up to the current period still perpetuate this common singular perspective on Batswana origins.

\section{Analysis of the colonial history syllabus and history texts}

An analysis of some of the history textbooks at this time throws up some interesting issues. Generally, as already pointed out above, the textbooks used during earlier colonial times featured the History of Bible Lands, the colonial administrative structure, emphasizing the South Africa link, as Bechuanaland Protectorate (presentday Botswana) was part of a larger Southern African political economy.

Other texts which were written along the same lines, highlighted the primacy of the colonial enterprise and the central role of the Tswana Dikgosi These were books such as, "Britain and her Neighbours," Stories from European History by Lucy Dale, A Brief History of the World by Niver. Others were, The Kings' Servants, published by Atlantic Press, More Kings Servants. The school history texts also included Colonial Reports, which placed emphasis on the structure of the colonial administration and the official activities, and the Official Yearbook of the Union of South Africa [3].

This collection of texts focused on the work of Imperial Service and Administration, particularly structure of the various departments of the Colonial Civil Service and their functions. The history syllabus was heavily tilted towards colonial and imperial history, including South African history, as Bechuanaland was part of the South African political hegemony. School history also included the colonial administration of Bechuanaland Protectorate. Where it incorporated indigenous issues, it featured personalities that were deemed to be important in the colonial socio-political discourse, and these were primarily Dikgosi who worked in close collaboration with the colonial government officials and missionaries.

It is interesting in particular to note that the work of the High Commissioner, the Resident Commissioner, the colonial administrative departments and key offices such as that of the Magistrate, the Chief and the Kgotla (traditional meeting place and administrative centre), the headman were all incorporated as part of the taught history. Included in the texts was one titled, An Account of the Rise and Fall of the Empire of the World from the Egyptian to the British Empire, and after 1914, the work of The League of Nations was integrated into the History syllabus [3]. It is also important to remember that up to early 1940's, history was only taught at primary school level in Bechuanaland Protectorate, because the first secondary school was established by the Roman Catholic Mission at Khale, in 1944 [9].

Some of the texts relating to Batswana history contained "historicised fiction", such as legends from principal groups, which were woven into school history texts [3] [11]. One such a legend, which was interwoven with history related to the legend of the founding of the Bangwato as a separate ethnic group [12]. According to the legend, the duiker saved Khama's life, and as a result, it was adopted as the Bangwato totem. An example of mythical history that was integrated into the history content as an aspect of indigenous history is the one on Lentswe la Baratani Hill of Lovers, about two lovers who as the tale has it, disappeared after climbing a hill in the Bamalete village of Otse in the southern part of present-day Botswana (This story is reproduced in Roy Gardner's A Primary History of Botswana [12]. The book was published in the early postindependence period. It is also important to note that this style of interweaving myth and legend into history was also evident in the early postcolonial period, no doubt a carry-over from earlier practice, but also indicated that history as a professional discipline in Botswana took a long time to develop, let alone to be inclusive.

The core history texts were also supplemented with Setswana stories in the later colonial period. These featured the first evangelists who were sent on mission northwards from amongst these groups, such as Mebalwe and Khukhu Mogodi, Sebolai Shomolekae, who came from Batlhaping and Bangwaketse, and Barolong respectively. Books with titles such as Moffat and "Shamolekai (sic)" [11]were prepared under the auspices of the Venturer Series and were used as history readers. The fact that evangelists such as Mebalwe and Shomolekae were members of principal groups was due to the fact that the mission started from the British Bechuanaland south of Bechuanaland Protectorate where the mission headquarters was based at Kuruman, and worked its way northwards into Northern Bechuanaland (Bechuanaland Protectorate). By virtue of their close association with missionaries, the hegemonic Batswana principal groups were also associated with "civilization". This often set them apart and "segregated" them from their more northern groups, with the exception of the Bangwato and Batawana groups, who are the offshoots of the principal Tswana stock.

It is interesting to note that while some books were written in English, other books which were used to teach history were written in the vernacular-usually 
Setswana and Sesotho, and also doubled as vernacular reading with historical content, as noted above. A case in point is a text compiled by missionary A.J. Wookey usually referred to as “Dico". Wookey's Dico tsa Secwana constituted the main history text for Bechuanaland [10]. It featured the history of the origins of principal Batswana ethnic groups, including their traditional leadership.

The other readers that were used in the teaching of history were based on the lives of past Batswana traditional leaders, while others dealt with the sociopolitical experiences of the principal Batswana ethnic groups. Cases in point are "Dinwao leha e le dipolelo ka ga Dico tsa Sechuana”, which chronicled traditions and customs of principal Batswana groups. It was prepared by the missionary A.J. Wookey, and "A Short History of Bakwena," which according to was prepared by missionaries in conjunction with Kgosi Sebele I of Bakwena [11]. Another early school history text, A Short History of the Native Tribes of the Transvaal (1905) gave details of the proto-Tswana ethnic groups, such as the genealogies of the rulers of Bakwena, Bangwato and Bangwaketse. The data was collected by missionary Edwin Lloyd and Kgosi Bathoen of Bangwaketse [21].

In these textbooks there was a conspicuous absence of minority ethnic groups, and of topics that reflected conflicts that occurred at the socio-cultural and political levels, between principal groups and ethnic minorities. Generally, the texts failed to include histories of ethnic minorities except only to emphasize their subordination by hegemonic Tswana, and only featured and largely served to legitimize the rule of the principal Tswana over the minority groups.

In the 1930's and 1940s, the histories of principal groups increasingly appeared side by side with those of the colonial administration. For example, in the 1931 Bechuanaland Code Syllabus, the history of traditional leadership was treated under topics such as The Chief and the Kgotla (Tswana administrative meeting place) and was featured alongside others such as "A Review of South Africa History; The High Commissioner of the Union of South Africa; The Administration of Bechuanaland Protectorate; The Magistrate, etc., [3] Another text which highlighted and exalted the role of Batswana principal Dikgosi in the colonial process was that of Frederich Madden's "The Cambridge History of the British Empire", Volume 3 (1967). It highlighted the manner in which the three leaders of principal groups, Dikgosi (traditional leaders) Khama of Bangwato, Bathoen of Bangwaketse, and Sebele of Bakwena were received in London [21]. They had gone there with the support of their missionary friends in order to protest the impending incorporation of their territory into imperialist Cecil John Rhodes' Southern Rhodesia.
The book also chronicles the support the three dikgosi received, and their appeal to the morality of the British middle class. This approach eventually swayed Lord Chamberlain into drafting the agreement, which became known as The Chamberlain Settlement. The agreement protected Batswana territory against encroachment from Rhodesia [21].

\section{Socio-political transformation and indigenous histories}

As colonial rule became more wore on, there were other developments, which created the context for, and facilitated more systematic incorporation of texts dealing with the histories of principal Batswana. In particular, the work of anthropologists in the 1930s suggested the need, and resulted in the incorporation of the "adaptation" principle into colonial development policy and planning. Anthropological work generally indicated that colonization had alienated the indigenous people from their culture and that it was necessary to institute measures to arrest this development mainly through adaptive curricula. Henceforth, syllabi were reoriented to ensure more reflection on and incorporation of indigenous way of life. In Bechuanaland Protectorate, the colonial government roped in the anthropologist Isaac Schapera in debates around these issues. In the ongoing debates, the Director of Education during the 1930s, H.J.E. Dumbrell also arranged visits and discussions with other experts on issues of reorientation and Africanization of the Bechuanaland Protectorate curricula.

The experts whose services were enlisted to assist in reformulating the colonial curriculum included the renowned anthropologist Isaac Schapera, and Victor Murray the author of the well known book, The School in the Bush [20], which emphasized the value of incorporating African perspectives and practices into the curriculum, and the need to modernize these, paying particular attention to issues of hygiene and nutrition. The Director of Education even arranged a visit by Victor Murray, then serving as Professor of Education at Hull University, a proponent of Africanization of the curriculum, to deliberate with the Board of Advice on Native education at its $3^{\text {rd }}$ meeting. At that meeting, the Resident Commissioner underscored the importance, and encouraged the production of vernacular literature and criticized book learning. His speech laid emphasis on "training that will suit the needs of a future peasant and craftsman-training of hand and eye-lessons of technical and agricultural subjects" [18]. In particular, he emphasized the importance of agriculture and handicrafts in educational deliberations. 
The encouragement of school gardens and the close cooperation between the Education Department and those of Health and Agriculture was a practical expression of this initiative. A joint committee, consisting of 3 Europeans and 3 Africans was set up and was tasked to work on production of textbooks that emphasized the African context. They included Isaac Schapera, Mr. Nettleton, a colonial government official, Reverend Haile, the principal of Tiger Kloof, an institution that mainly catered for the educational needs of Batswana, Mr. Peter Sebina, an educated inhabitant of Serowe, ex-Chief Isang Pilane of Bakgatla, Reverend A. Kgasa and Mrs. Rey, the only woman member. In the subject of history, the reorientation of mindset facilitated debates around the need for, and the gradual incorporation of indigenous histories. However, the fact that these educational bodies only roped in the recognized Batswana traditional leaders who happened to be leaders of principal groups meant that only the histories of these groups were featured prominently.

In related developments, the work of the Board of Advice on Native Education and the Native Advisory Council (later the African Advisory Council) was preoccupied with themes of adaptation of education to the needs of a rural, peasant society. The nature of this work was a tacit expression of the need for Africans views to be incorporated into policy formulation and implementation in order to achieve this objective. The members of the Council comprised the indigenous leadership and their advisors who were mainly educated elite members of their communities, constantly debated educational and general developmental issues affecting their country. The makeup of the Council generally skewed the school history texts and teaching towards the histories of the principal Batswana groups, and laid a foundation for continued marginalization of minority group histories. This is the scenario that was inherited at independence time, and which continues to create a challenge that makes it difficult to forge a common inclusive history curriculum in Botswana.

\section{Conclusion}

The colonial discourse generally placed the royalty of the dominant groups and their functionaries at the centre, whilst the histories of the peripheral groups were entirely excluded or misrepresented, where featured. Generally, the context and content of history tended to reflect the broader socio-political milieu. Accordingly, much of the history that was taught during the missionary and colonial periods reflected firstly, Britain's political hegemony over the inhabitants of Bechuanaland Protectorate, and secondly, Tswana hegemony over the subject groups.
The history content primarily featured the history of Britain and church history, with an emphasis on bible lands and the colonial administrative and processes, from a purely Euro-centric perspective. Where it was accommodated, indigenous history was presented monolithically, as that of a people with a singular identity deriving from their purported common origins, which regarded them all as originating from a common founder. The historical versions of Batswana origins they appear in the history books used in the education system up to the current period still perpetuates this common singular perspective of Batswana origins. This is the legacy that was adopted by the post-colonial government, which continues to present challenges with regard to formulation of an inclusive history syllabus.

\section{References}

[1]Akintoye, S.A. Emergent African states: Topics in $20^{\text {th }}$ century African history, Longman Group, London, 1977.

[2]Andersson, L-G. \& Janson, T. Rich and poor languages in Botswana, in Granqvist, R. Culture in Africa: An appeal for pluralism, Seminar Proceedings 29, Uppsala, Scandanavian Institute of African Studies, 1993, pp 79-85.

[3] Bechuanaland Protectorate Code 1931, Botswana Notes and Records (BNA) 11481931.

[4] Bechuanaland Protectorate, Blue Books, 1912/131927/8: Botswana National Archives BNA S45; BNA S604/3.

[5] Bobeng, M. The Bangwato-Babirwa conflict in the late $19^{\text {th }}$ and early $20^{\text {th }}$ Centuries, BA Dissertation, History Department, University of Botswana, 1976.

[6] Botswana Government, Education for Kagisano, National Commission on Education Report (NCE), Government Printer, Gaborone, April 1977.

[7] Botswana Daily News, Speech of Honourable Minister of Education, Kebatlamang Morake, Government Printer, Gaborone, March $12^{\text {th }} 1975$.

[8] Chirenje, M.J. A History of Northern Botswana, 18501910, Associated University Press, London, 1977

[9] Colclough, C. \& McCarthy, S. The political economy of Botswana: A study of growth and distribution,

[10] Correspondence, from Alice Young, Phalapye to Mr. Cousins, Acting Foreign Secretary, LMS, July (day not indicated), 1897; Incoming letters, 1797-1927, Council of World Mission Archives: Southern Africa, BNA, H2130 2ng 1978, Boxes 1-89.

[11] Doke, C.M. (1935) Vernacular textbooks in South African native schools, Africa: Journal of the International African Institute, volume 8, no.2, pp47-71.

[12] Gardner, R., A Primary history of Botswana, Longmaa, Gaborone, 1971. 
[13]Kowet, D.K. Land, labour migration and politics in Southern Africa, African Publishing Company and Scandanavian Institute of African Studies, New York and Uppsala, 1978.

[14] Mafela, L. Gender and ideology in education in Bechuanaland Protectorate, c.1840-1945, Unpublished $\mathrm{PhD}$ Dissertation, Northwestern University, Illionois, 1993.

[15] Mautle, G.T. The Bakgalagadi-Bakwena relationship: A case study, in Botswana Notes and Records (BNA), volume 18, pp19-31.

[16] Mazrui, A, \& Mazrui, A, The Power of Babel: Language and governance in the African experience: Language and the African experience, James Currey, London, 1998.

[17] Maylam, P. Rhodes, The Tswana and the British: Colonialism, collaboration in Bechuanaland Protectorate, Greenwood Press, Westport, 1980.

[18] Minutes of the Board of the Advice on Native Education at its $3^{\text {rd }}$ Meeting, Mafeking, $9^{\text {th }}$ August, 1934, BNA S98/12.

[19] Mongwa, M.D.K. The political struggles of BakaNswazi under John Madawo and Bangwato under Tshekedi Khama, 1926-1932, BA Thesis, History department, University of Botswana, 1977.

[20] Murray, V. School in the bush. A critical study of the theory and practice of native education in Africa, Frank Cass and Company, London, 1929.

[21] Parsons, N. King Khama, Emperor Joe, and the Great White Queen: Victorian Britain through African eyes, Chicago University Press, Chicago, 1998.

[22] Parsons, N. \& Crowder, M. (eds) Monarch of all I survey: Bechuanaland diaries, 1929-37 by Sir Charles Rey, Botswana Society, Gaborone, 1988.

[23] Ranger, T. African attempts to control education in East and Central Africa, Past and Present, volume 30, 1965, pp57-85.

[24] Republic of Botswana, Education for a Nation, Address By His Excellency the President Sir Seretse Khama to the Botswana Teachers Union Conference at Lobatse, Government Printer, Gaborone, December $15^{\text {th }}$, 1969, BNB 1505.

[25] Sekgwama, J. Z., (1987), Babirwa-Bangwato Relations, 1920-1966, BA Dissertation, History Department, University of Botswana, Gaborone.

[26] Thema, B.C. The development of native education in the Bechuanaland Protectorate: A historical survey, 18401946, in partial fulfillment of the MEd. degree of the University of South Africa, 1946.
[27] Vickers, E., Kan, F. \& Morris, P. Colonialism and the politics of Chinese history in Hong Kong schools, Oxford Review of Education, volume. 29, no.1, pp 95-111. 